\title{
A systematic review of potential habitat suitability for the jaguar Panthera onca in central Arizona and New Mexico, USA
}

\author{
Eric W. Sanderson, Kim Fisher, Rob Peters, Jon P. Beckmann, Bryan Bird \\ Curtis M. Bradley, Juan Carlos Bravo, Melissa M. Grigione \\ James R. Hatten, Carlos A. Lopez González, Kurt Menke \\ Jennifer R. B. Miller, Philip S. Miller, Cristina Mormorunin \\ Michael J. Robinson, Robert E. Thomas and Sharon Wilcox
}

\begin{abstract}
In April 2019, the U.S. Fish and Wildlife Service (USFWS) released its recovery plan for the jaguar Panthera onca after several decades of discussion, litigation and controversy about the status of the species in the USA. The USFWS estimated that potential habitat, south of the Interstate-10 highway in Arizona and New Mexico, had a carrying capacity of c. six jaguars, and so focused its recovery programme on areas south of the USA-Mexico border. Here we present a systematic review of the modelling and assessment efforts over the last 25 years, with a focus on areas north of Interstate-10 in Arizona and New Mexico, outside the recovery unit considered by the USFWS. Despite differences in data inputs, methods, and analytical extent, the nine previous studies found support for potential
\end{abstract}

ERIC W. SANDERSON (Corresponding author, (1) orcid.org /0000-0002-7477-0193) and Kiм FIsHer Global Conservation Program, Wildlife Conservation Society, New York, USA. E-mail esanderson@wcs.org

Rob Peters, Bryan Bird and Sharon Wilcox Field Conservation, Southwest Office, Defenders of Wildlife, Santa Fe, USA

Jon P. Beckmann and Cristina Mormorunni Rocky Mountain West Program, Wildlife Conservation Society, Santa Fe, USA

Curtis M. Bradley Geographic Information Systems, Center for Biological Diversity, Tucson, USA

Juan Carlos Bravo Mexico and Borderlands Program, Wildlands Network, Salt Lake City, USA

Melissa M. Grigione Biology Department, Pace University, Pleasantville, USA

James R. Hatten Western Fisheries Research Center, US Geological Survey, Cook, USA

Carlos A. Lopez GonzÁlez Facultad de Ciencias Naturales, Universidad Autonoma de Queretaro, Queretaro, Mexico

KURT MENKE Geographic Information Systems, Bird’s Eye View, Albuquerque, USA

JenNifer R. B. Miller Center for Conservation Innovation, Defenders of Wildlife, Washington, DC, USA

PhiLIP S. Miller Conservation Planning Specialist Group, IUCN, Apple Valley, USA

Michael J. Robinson Endangered Species Program, Center for Biological Diversity, Silver City, USA

ROBERT E. ThOMAs Bordercats Working Group, Lakewood, USA

Received 13 December 2019. Revision requested 2 March 2020.

Accepted 19 May 2020. First published online 16 March 2021. suitable jaguar habitat in the central mountain ranges of Arizona and New Mexico. Applying slightly modified versions of the USFWS model and recalculating an Arizonafocused model over both states provided additional confirmation. Extending the area of consideration also substantially raised the carrying capacity of habitats in Arizona and New Mexico, from six to 90 or 151 adult jaguars, using the modified USFWS models. This review demonstrates the crucial ways in which choosing the extent of analysis influences the conclusions of a conservation plan. More importantly, it opens a new opportunity for jaguar conservation in North America that could help address threats from habitat losses, climate change and border infrastructure.

Keywords Ecological restoration, historical range, jaguar, Panthera onca, rewilding, spatial model, species distribution model, USA

Supplementary material for this article is available at doi.org/10.1017/So030605320000459

\section{Introduction}

Tn April 2019, the U.S. Fish and Wildlife Service (USFWS) 1 released its recovery plan (USFWS, 2018) for the jaguar Panthera onca after several decades of litigation and controversy about the status of, and the future for, this felid in the USA. The jaguar is listed as an endangered species in the USA (USFWS, 1972) and categorized as Near Threatened on the IUCN Red List (Quigley et al., 2017). Here we contribute to these debates by documenting potential habitat for the jaguar in the central mountains of Arizona and New Mexico, an area not considered in the latest recovery plan, and explore the implications of this additional area for conservation of the species as a whole.

The USFWS jaguar recovery plan described two geographical units of jaguar conservation, and recovery criteria for each. The Pan-American Recovery Unit encompassed all the jaguar's range, from Argentina to the USA. The Northwestern Jaguar Recovery Unit delineated jaguar habitat in north-west Mexico and the south-west USA, 
extending from Colima State, along the western slope of the Sierra Madre Occidental Mountains, into the Sky Island mountain ranges of northern Sonora, south-eastern Arizona and south-western New Mexico. The USFWS drew the northern edge of both units at the Interstate-10, suggesting this highway represents the natural northern extent of jaguars in the Americas (Fig. 1). The northernmost recovery unit was further subdivided into core and secondary areas, including the Borderlands Secondary Area-U.S. Portion, which comprised parts of Arizona and New Mexico south of Interstate-10. Analysis within the recovery plan suggested that the potential carrying capacity in the USA (within the Borderlands Secondary Area-U.S. Portion) was only six jaguars and, therefore, the plan's recommended recovery actions focused primarily south of the USA-Mexico border (USFWS, 2018; also see Sanderson \& Fisher, 2013).

This conclusion is at odds with several other habitat studies covering areas north of Interstate-10. Numerous photographs, physical remains, and accounts of jaguars from the late 19th century to the 196os (Brown \& Lopez González, 2001) demonstrate that the species formerly occurred north of the current highway (the highway dates from 1956). Ironically some of these historical jaguar records came from hunters working for the U.S. Bureau of Biological Survey and its successor organizations, as part of predator control efforts. Some of these government hunters placed jaguar skulls and skins in the U.S. National Museum (for example, Russell Culbreath's kill on the White Mountain Apache Indian Reservation in 1964; USNM 289015). Other accounts come from ranchers, trappers, hunters and tourists, including of jaguars killed near the Grand Canyon. These observations are cited in a long series of summary papers and books, published since the 1920s, and now available online (Sanderson \& Fisher, 2011; USFWS \& Wildlife Conservation Society, 2020).

Because jaguar observations are infrequent and difficult to confirm even when they do occur, and because jaguars have been extirpated from areas where prey and vegetative cover still remain, researchers have turned to various modelling approaches to estimate the geographical distribution of potential jaguar habitat in Arizona and New Mexico. There have been nine such previous efforts by academic researchers, government wildlife managers, and private conservation organizations, published before the USFWS (2018) recovery plan. Some of these models have been described in the peer-reviewed literature (e.g. Boydston \& Lopez González, 2005; Hatten et al., 2005), whereas others have only been described in reports, despite their use in various legal, political and scientific contexts, including the recovery plan.

Here we conduct the first systematic review (sensu Pullin \& Stewart, 2006) of the existing modelling and assessment efforts, with a focus on areas north of Interstate-10 in Arizona and New Mexico (Fig. 1). Not all of these studies

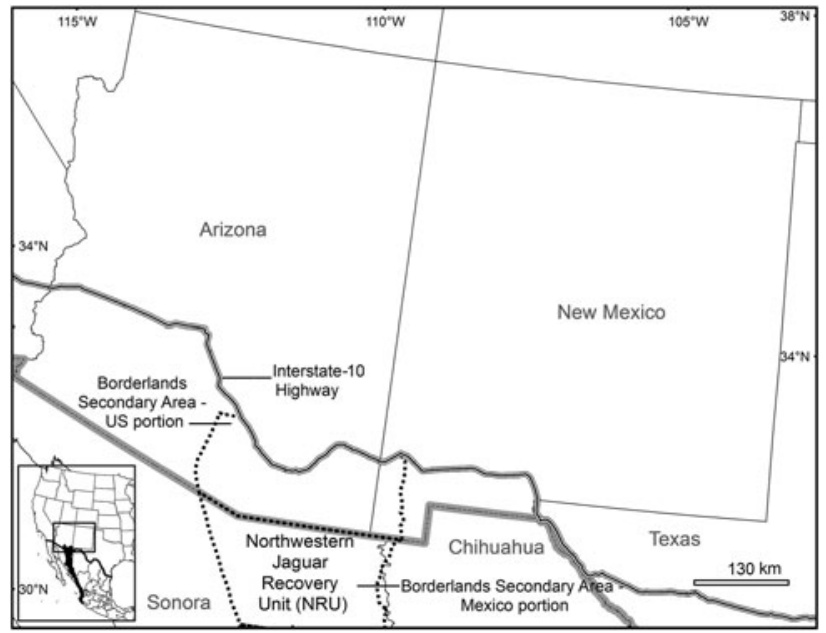

FIG. 1 Study area, with the Northwestern Recovery Unit for the jaguar Panthera onca and subsections delineated as described in USFWS (2018). The extent of the recovery unit in the USA and Mexico is shown on the inset map.

have been peer reviewed, so we provide sufficient information for the methods and results of each model or assessment to be evaluated and compared (Supplementary Material 1). We also present two northward extensions of the model used by the USFWS (2018) analysing this previously unconsidered area, and an update of a third model (Hatten et al., 2005), for a total of 12 treatments. We critically compare the methods and results. Through empirical examination of convergence among the models and assessments, we draw a boundary of a third potential recovery area, tentatively titled the Central Arizona/New Mexico Recovery Area.

Because legal definitions of range and status drive federal and state action on species conservation in the USA, we briefly summarize this history below.

\section{History of jaguar conservation in the USA}

The legal definition of jaguar range in the USA has been disputed for nearly 50 years. In 1972, jaguars were first added to the List of Foreign Species protected under the U.S. Endangered Species Conservation Act of 1969 (USFWS, 1972), with a note that the species was found in Central and South America. This listing ignored the numerous wellattested, historical observations of jaguars north of the border. In 1973, a new Endangered Species Act lead to a new consolidated List of Endangered and Threatened Wildlife, published in 1975 (USFWS, 1975). The new list included the jaguar with a note that its 'normal, known distribution' was 'Central and South America'. Furthermore, the notice explicitly noted that listed species, such as the jaguar, were protected 'wherever found'. In 1979, USFWS gave notice 
that 'through an oversight', populations of jaguars (and several other species) in the USA were not covered by the endangered classifications given to the species as a whole, but that this oversight would be rectified 'as quickly as possible' (USFWS, 1979). In 1980, USFWS proposed listing the jaguar as endangered in the USA, but the rule was never finalized (USFWS, 1980; USFWS, 1982).

In 1982, USFWS noted there was no resident or breeding population in the USA at the time, although 'stragglers occasionally wander into New Mexico, Arizona, and Texas, where they are generally shot as unwanted predators' (USFWS, 1982). In 1986, a rancher killed a jaguar in southern Arizona (Brown \& Lopez González, 2001). Two years later he and another man were convicted of illegal interstate sales and conspiracy for trying to sell the hide (and two others) in New Mexico (Associated Press, 1988).

In 1990, a recovery plan for Listed Cats of Texas and Arizona (with Emphasis on the Ocelot) noted in its introduction that 'Felis (Panthera) onca have been documented as either transient or resident in Arizona and/or Texas', but made no specific recommendations for jaguar conservation (USFWS, 1990). In 1994, a new proposal for listing the jaguar in the USA acknowledged that 'A minimum of 64 jaguars have been killed in Arizona since 1900' (USFWS, 1994). In 1996 two different jaguars were separately photographed by hunters in clearly arid habitats in south-east Arizona (Glenn, 1996; Childs, 1998). These were the first photographs ever taken of live jaguars in the USA. After litigation initiated by the Center for Biological Diversity, in 1997 USFWS re-designated jaguars as endangered in the USA (USFWS, 1997). But the agency also determined that designating critical habitat was 'not prudent' because 'publication of detailed critical habitat maps and descriptions in the Federal Register would likely make the species more vulnerable to prohibited activities' (such as the killing in 1986).

Jaguars recurred north of the border, nonetheless. Camera traps recorded regular use of the rugged mountains of extreme south-eastern Arizona and adjacent south-western New Mexico (McCain \& Childs, 2008). In 2006, the USFWS determined that a recovery plan would not promote the conservation of the species, because, they argued, the USA provided such a small fraction of habitat to the species range-wide (USFWS, 2006). This argument was challenged in court, and overturned in 2009. Fuelling the disputes, a jaguar first observed in the late 1990s, Macho B, was captured, injured, and subsequently euthanized by Arizona state officials in 2009 (U.S. Department of the Interior, 2010). Rapid land development (Povilitis, 2002) and the expansion of activity and infrastructure along the border to thwart illegal immigration (Peters, 2017) added urgency to the protection of the jaguar.

Given these events, and in response to lawsuits from the Center for Biological Diversity and Defenders of Wildlife, in 2010, USFWS decided it was prudent to declare critical habitat for the jaguar within the USA and initiated a recovery planning process (USFWS, 2010). In 2014, USFWS designated 309,263 ha of critical jaguar habitat, in southern Arizona and south-western New Mexico (USFWS, 2014), although later a court ruling found the designation invalid (Bies, 2020). A draft recovery plan was released for public comment in 2016 (USFWS, 2016). The recovery plan was finalized in 2018 (USFWS, 2018) and released to the public the following spring. After 48 years of controversy, the northern edge of jaguar range had legally moved $110 \mathrm{~km}$ from the international border to Interstate-10.

\section{Methods}

We followed the procedure for systematic reviews in ecology and conservation recommended by Pullin \& Stewart (2006), taking care to be transparent, objective and comprehensive (O'Leary et al., 2016). Our focal question was: Do scientific models and assessments of potential habitat for the jaguar Panthera onca in Arizona and New Mexico indicate suitability in areas north of Interstate-10? If so, which areas (Fig. 1)? To answer this question, we developed a review protocol based on inclusion criteria. Studies to be reviewed must have: (1) examined at least some areas that fall within the modern boundaries of the States of Arizona and/or New Mexico, in the USA (spatial criteria), (2) employed objective habitat criteria in a model or assessment based on documented aspects of jaguar ecology (scientific criteria), and (3) been documented thoroughly enough that the methods and results can be peer-reviewed (reviewable criteria). By 'model' we mean a spatial model, computed in a GIS, using a systematic method. By 'assessment' we mean any other evaluation of jaguar status in this region that meets the criteria above.

To locate these studies we searched using the search terms ('jaguar' OR 'Panthera onca') AND ('Arizona' OR 'New Mexico' OR 'United States') in the Web of Science (Clarivate Analytics, Philadelphia, USA), JSTOR (Ithaka Harbors, New York, USA), science.gov (a search engine for U.S. Federal Government scientific publications), and examined the first 100 results of a search on Google Scholar (2019). We also reviewed all the materials cited in the USFWS (2018) recovery plan and posted online by USFWS Arizona Ecological Services (2019), Arizona Department of Game and Fish (2019), and New Mexico Department of Game and Fish (2019). Finally, we contacted individuals who had conducted habitat studies that met our criteria, based on our first round of review, and asked if they knew of any additional efforts to include in this study.

For each model or assessment that met the criteria (Fig. 2), we summarized the stated purpose of each analysis, the extent, the data inputs, a brief description of the modelling methods and results (Supplementary Material 1), and 

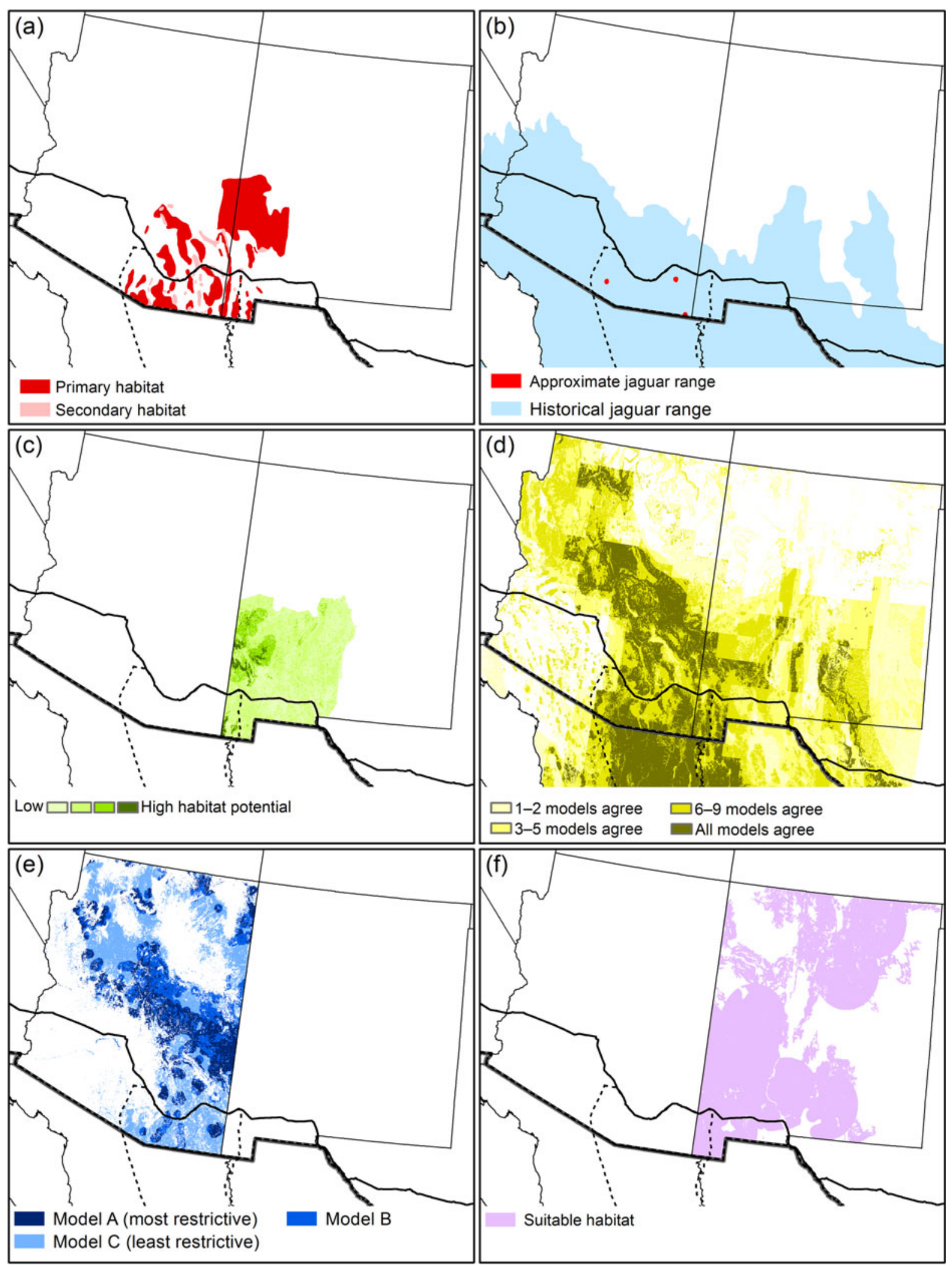

FIG. 2 Comparison of jaguar habitat models for Arizona and New Mexico: (a) Sierra Institute (200o), (b) Sanderson et al. (2002b), (c) Menke \& Hayes (2003), (d) Boydston \& Lopez González (2005), (e) Hatten et al. (2005), (f) Robinson et al. (2006), (g) Grigione et al. (2009), (h) Theobald et al. (2017; note percentage thresholds defined by habitat values in Arizona and New Mexico), (i) USFWS (2018) (model 13), (j) model 14 (this study), (k) model 15 (this study), (l) Hatten (this study). 

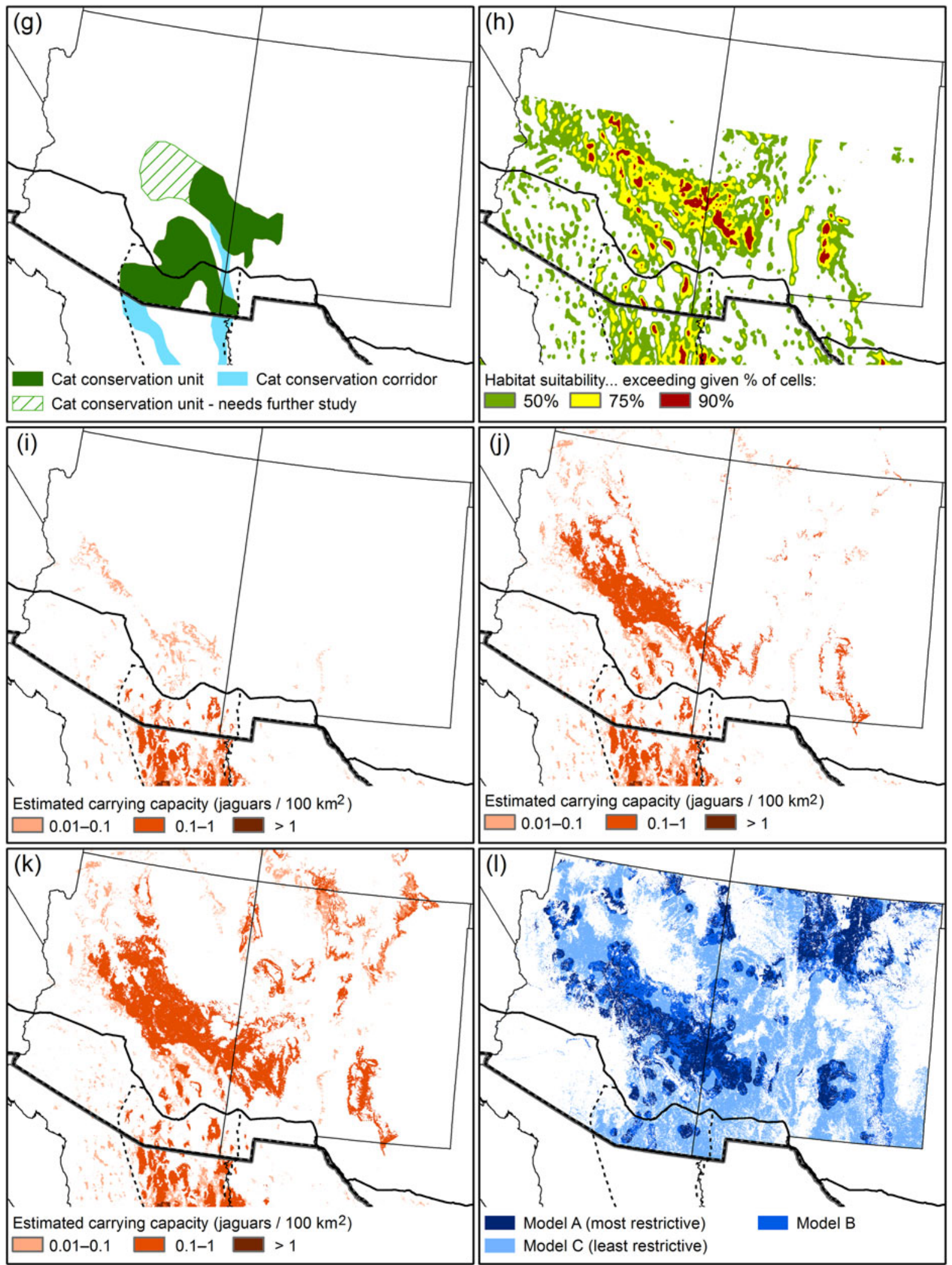

Fig. 2 (Cont.)

obtained the relevant GIS layers, if possible. For the Sierra Institute (2000) analysis, we georeferenced and digitized the model figure.
In a new analysis, we also extended the USFWS (2018) model to the area north of Interstate-10 as described below. Previously USFWS (2018) assessed the distribution of jaguar 


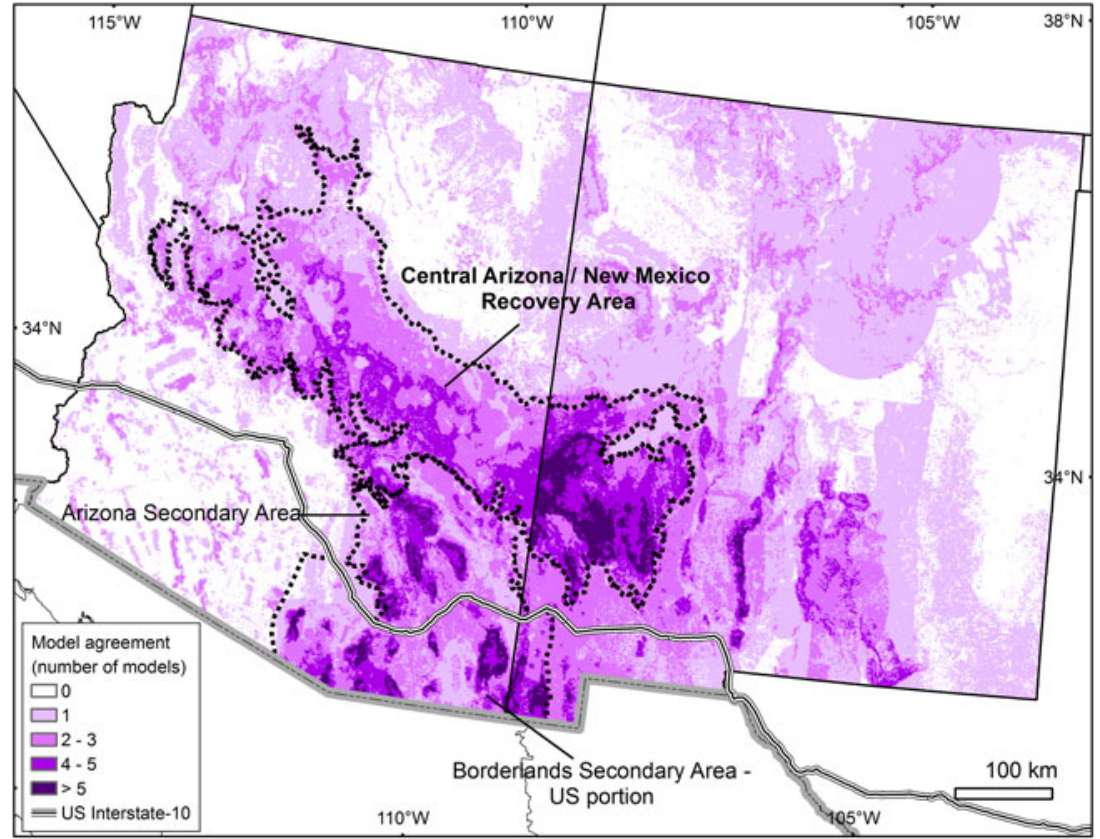

FIG. 3 Areas of convergence of potential jaguar habitat models in central Arizona and New Mexico beyond the northern edge of the Northwestern Jaguar Recovery Unit described in USFWS (2018). observations from all of the Northwestern Recovery Unit (Sanderson \& Fisher, 2011) against putative habitat variables individually, and combined them with a simple, multivariate model. Input variables were reclassed to include areas with $>1$ and $\leq 50 \%$ tree cover, intermediate, moderate and high ruggedness (defined in Riley et al., 1999), and within $10 \mathrm{~km}$ of a waterway (Hatten et al., 2005). Areas of high human influence (defined as a human influence index $>20$; Sanderson et al., 2002a) and above 2,000 m elevation were excluded from the potential distribution. The technical sub-team of the USFWS recovery team assigned weights based on observed jaguar densities in different ecoregions (Olson et al., 2001), with highest weights provided to the subtropical, dry and moist forest ecoregions of Mexico. Lower weights were assigned to pine and pine-oak forest types, and lowest weights to desert ecoregions. Ecoregions lying entirely outside the pre-determined Northwestern Recovery Unit boundary (notably, Arizona Mountain Forests) were excluded. The habitat suitability model was translated to jaguar densities (jaguars/10o $\mathrm{km}^{2}$ ) by regressing densities in study areas against mean habitat values for those areas, with the $y$-intercept forced through zero (USFWS, 2018). Various iterations of this model were documented in Sanderson \& Fisher (2013); the final version used in the recovery plan was labelled 'model 13'.

We extended the USFWS (2018) model over the rest of Arizona and New Mexico by assigning the Arizona Mountain Forest, Colorado Plateau Shrubland, and Colorado Rocky Mountain Forest ecoregions (Olson et al., 2001) the model weights $0.1,0.01$ and 0.1 , respectively (model 14). Jaguar observations have been reported from all of these ecoregions historically (Brown \& Lopez González, 2001). We also computed a second extension, raising the elevation cut-off from 2,000 to $2,400 \mathrm{~m}$ (model 15 ). There is no known biological basis for a 2,000 m cut-off. Jaguars are known to use areas up to 2,80o $\mathrm{m}$ in Jalisco, Mexico (Nunez-Perez, pers. comm., cited in USFWS, 2018), and a jaguar was shot at an elevation of 2,850 $\mathrm{m}$ in the White Mountains of Arizona in 1963 (Brown \& Lopez González, 2001; Davis, 2013). Conservatively, we set our limit at $2,400 \mathrm{~m}$, the approximate upper limit of pine-oak forest assemblages in Arizona (Patton et al., 2014).

We also extended the Hatten et al. (2005) model over the entirety of Arizona and New Mexico, with some substitutions of higher-quality GIS data, notably the NHDPlus (data model version 2.1) database (McKay et al., 2012), the GAP/LANDFIRE National Terrestrial Ecosystems database (Homer et al., 2015), and the 30-m National Elevation Dataset (Archuleta et al., 2017). These improvements enabled the new model (Hatten, this study) to be expressed at $30 \mathrm{~m}$ resolution.

Finally, we overlaid the models to find areas of congruence by projecting to a common coordinate system and rescaling the data to $1 \mathrm{~km}^{2}$ resolution (Fig. 3) to highlight the area we term the Central Arizona/New Mexico Recovery Area. This research was conducted during AprilDecember 2019.

\section{Results}

\section{Literature review}

We reviewed 469 documents identified through the literature search. Ultimately, nine papers or reports met the inclusion criteria: Sierra Institute (2000), Sanderson et al. (2002b), Menke \& Hayes (2003); Boydston \& Lopez González 
TABLE 1 Comparison of data inputs to estimated jaguar Panthera onca habitat models and assessments, including the three new models in this study, covering some or all of Arizona and New Mexico. For additional details see Supplementary Material 1.

\begin{tabular}{|c|c|c|c|c|c|c|c|c|c|c|c|c|}
\hline \multirow[b]{2}{*}{ Model or assessment } & \multirow[b]{2}{*}{ Spatial extent ${ }^{1}$} & \multicolumn{11}{|c|}{ Categories of data inputs } \\
\hline & & $\begin{array}{l}\text { Climatic } \\
\text { variables }\end{array}$ & $\begin{array}{l}\text { Ecosystem/ } \\
\text { land use/ } \\
\text { land cover }\end{array}$ & Elevation & $\begin{array}{l}\text { Expert } \\
\text { opinion/ } \\
\text { variable } \\
\text { choice }\end{array}$ & $\begin{array}{l}\text { Human } \\
\text { disturbance }\end{array}$ & $\begin{array}{l}\text { Jaguar } \\
\text { observations }\end{array}$ & $\begin{array}{l}\text { Prey } \\
\text { base }\end{array}$ & $\begin{array}{l}\text { Vegetation } \\
\text { cover }^{2}\end{array}$ & $\begin{array}{l}\text { Soil } \\
\text { type }\end{array}$ & $\begin{array}{l}\text { Topographic } \\
\text { variation }\end{array}$ & $\begin{array}{l}\text { Water } \\
\text { (presence of/ } \\
\text { distance to) }\end{array}$ \\
\hline Sierra Institute (2000) & $\begin{array}{l}\text { Sky Islands } \\
\text { region }\end{array}$ & & $\mathrm{X}$ & & $\mathrm{X}$ & $\mathrm{X}$ & $\mathrm{X}$ & $\mathrm{X}$ & & & & $\mathrm{X}$ \\
\hline Sanderson et al. (2002b) & Range-wide & & & & $\mathrm{X}$ & & $\mathrm{X}$ & & & & & \\
\hline Menke \& Hayes (2003) & Parts of NM & & $\mathrm{X}$ & & $\mathrm{X}$ & $\mathrm{X}$ & $\mathrm{X}$ & $\mathrm{X}$ & & & $\mathrm{X}$ & $\mathrm{X}$ \\
\hline $\begin{array}{l}\text { Boydston \& Lopez } \\
\text { González (2005) }\end{array}$ & $\begin{array}{l}\text { AZ, NM, parts } \\
\text { of TX \& SON }\end{array}$ & $\mathrm{X}$ & & $\mathrm{X}$ & $\mathrm{X}$ & & $\mathrm{X}$ & & & $\mathrm{X}$ & $\mathrm{X}$ & $\mathrm{X}$ \\
\hline Hatten et al. (2005) & $\mathrm{AZ}$ & & $\mathrm{X}$ & $\mathrm{X}$ & $\mathrm{X}$ & $\mathrm{X}$ & $\mathrm{X}$ & & & & $\mathrm{X}$ & $\mathrm{X}$ \\
\hline Robinson et al. (2006) & NM & & $\mathrm{X}$ & & $\mathrm{X}$ & $\mathrm{X}$ & $\mathrm{X}$ & & & & $\mathrm{X}$ & $\mathrm{X}$ \\
\hline Grigione et al. (2009) & $\begin{array}{l}\text { AZ, NM, TX, } \\
\text { SON, CHI, } \\
\text { COA, NLE, } \\
\text { TAM }\end{array}$ & & & & $\mathrm{X}$ & & $\mathrm{X}$ & & & & & \\
\hline Theobald et al. (2017) & NRU & & & & $\mathrm{X}$ & $\mathrm{X}$ & $\mathrm{X}$ & & $\mathrm{X}$ & & $\mathrm{X}$ & \\
\hline USFWS (2018) (model 13) & NRU & & $\mathrm{X}$ & $\mathrm{X}$ & $\mathrm{X}$ & $\mathrm{X}$ & $\mathrm{X}$ & & $\mathrm{X}$ & & $\mathrm{X}$ & $\mathrm{X}$ \\
\hline Model 14 (this study) & $\mathrm{AZ}, \mathrm{NM}$ & & $\mathrm{X}$ & $\mathrm{X}$ & $\mathrm{X}$ & $\mathrm{X}$ & $\mathrm{X}$ & & $\mathrm{X}$ & & $\mathrm{X}$ & $\mathrm{X}$ \\
\hline Model 15 (this study) & $\mathrm{AZ}, \mathrm{NM}$ & & $\mathrm{X}$ & $\mathrm{X}$ & $\mathrm{X}$ & $\mathrm{X}$ & $\mathrm{X}$ & & $\mathrm{X}$ & & $\mathrm{X}$ & $\mathrm{X}$ \\
\hline Hatten (this study) & $\mathrm{AZ}, \mathrm{NM}$ & & $\mathrm{X}$ & $\mathrm{X}$ & $\mathrm{X}$ & $\mathrm{X}$ & $\mathrm{X}$ & & & & $\mathrm{X}$ & $\mathrm{X}$ \\
\hline
\end{tabular}

${ }^{1}$ AZ, Arizona; NM, New Mexico; TX, Texas; SON, Sonora; CHI, Chihuahua; COA, Coahuila; NLE, Nuevo Leon; TAM, Tamaulipas; NRU, Northern Recovery Unit (USFWS, 2018).

${ }^{2}$ Remotely sensed continuous cover. 
(2005), Hatten et al. (2005), Robinson et al. (2006), Grigione et al. (2009), Theobald et al. (2017) and USFWS (2018). We also identified some early or derivative reports (e.g. Hatten et al., 2002; Sanderson \& Fisher, 2013; Bravo \& Davis, 2017), but excluded them because they were largely duplicative of other studies (Hatten et al., 2005; USFWS, 2018; and Theobald et al., 2017, respectively.)

\section{Comparison of potential habitat models and assessments} for the jaguar

Comparing models (see details in Supplementary Material 1), we documented 11 categories of information used to assess jaguar habitat potential (Table 1; Supplementary Table 1). All assessments used expert opinion to some extent, although two studies were driven almost entirely by expert consensus: Sanderson et al. (2002b) and Grigione et al. (2009). The range-wide assessment (Sanderson et al., 2002b) was limited in Arizona and New Mexico by a historical distribution boundary from Seymour (1989), which stopped at the northern edge of the Sonoran and Chihuahuan deserts. The study of Grigione et al. (2009) supplemented Sanderson et al. (2002b), using similar methods to collect observational data and redraw areas of knowledge and potential habitat for the jaguar farther north. These techniques have largely been supplanted by more quantitative spatial modelling techniques used in other models.

Variable selection differed across the models. All 10 models/assessments considered jaguar observations of some kind; seven considered topographic variation or terrain ruggedness; seven considered presence of, or distance to, water; and seven included some measure of human disturbance. Six models included maps of ecosystems or land use/ land cover. Four assessments used elevation thresholds. Only two models/assessments included explicit consideration of prey base (Sierra Institute, 2000; Menke \& Hayes, 2003). The three most recent models (Theobald et al., 2017; USFWS, 2018; this study) use remotely sensed measurements of vegetative cover. Only Boydston \& Lopez González (2005) used soil types and climate variables.

The treatment of variables varied in terms of grain and extent, both spatially and temporally. The spatial extents of models ranged from one or more parts of a state to encompassing multiple states in the USA and Mexico (Table 1). The spatial grain or resolution varied from $25 \mathrm{~km}^{2}$ (Boydston \& Lopez González, 2005) to $30 \mathrm{~m}^{2}$ (Theobald et al., 2017). Three were vector-based (Sierra Institute, 2000; Sanderson et al., 2002b; Grigione et al., 2009); all others were rasterbased analyses. Although all models/assessments included jaguar observations, they varied considerably as to which observations were included. As noted above, USFWS (2018) only included ecoregions that overlapped the Northwestern Recovery Unit, thereby excluding from consideration many areas with older observations, including much of the area analysed here. Robinson et al. (2006) detailed 18 observations from New Mexico, only one of which was used in the USFWS (2018) recovery plan (i.e. Glenn's, 1996, photograph from the Peloncillo Mountains). Hatten et al. (2005) used 25 sighting records from Arizona for 1901-2001. Theobald et al. (2017) used only observations with reliable geographical coordinates for 1917-2017.

Modelling methods also varied. As noted above, the Sanderson et al. (2002b) and Grigione et al. (2009) assessments were largely expert-driven, drawing polygons on maps through consensual procedures. Of the spatial models, six were variants of overlays of relevant habitat variables, usually with some kind of weighting system, examining areas of spatial congruence of relevant variables, including Menke \& Hayes (2003), Hatten et al. (2005), Robinson et al. (2006), Theobald et al. (2017), USFWS (2018) and this study. Most of these six studies combined variables additively to generate a habitat index; Theobald et al. (2017) combined them multiplicatively. The Sierra Institute (2000) used overlay techniques, but the resulting map appears to have been hand-drawn. Boydston \& Lopez González (2005), in contrast, used the Genetic Algorithm for Rule Set Production software (Sachetti-Pereira, 2002).

For the spatial models, nearly all were expressed in unitless indices of jaguar habitat suitability on different scales. The primary exception was the model used by the USFWS Recovery Plan (USFWS, 2018; i.e. model 13) and its extensions in this paper (models 14 and 15), which were translated to estimates of potential jaguar density, based on regression analysis between the habitat index and density measurements. This translation enabled estimates of potential carrying capacity for jaguars in different polygonal areas, such as the subunits of the Northwestern Recovery Unit.

\section{Areas of congruence}

Despite these differences in variable selection, spatial and temporal extent, and model formulation, the results are remarkably consistent about the potential jaguar habitat north of the Interstate-10 highway in Arizona and New Mexico (Figs 2 \& 3). The congruence is sufficient to draw a boundary around what we call the jaguar's Central Arizona/New Mexico Recovery Area. For convenience, we followed the boundaries of the Arizona/New Mexico Mountains Level III ecoregion of the U.S. Environmental Protection Agency (Omernik \& Griffith, 2014; see also Griffith et al., 2014), which in turn is similar to the Arizona/New Mexico Forests (Olson et al., 2001) and northern portions of the Madrean Evergreen Forest ecosystem (Brown, 1994). We also delineated a connector area from to the USFWS (2018) Northwestern Recovery Unit called the Arizona Secondary Area. 
TABLE 2 Areas of and per cent overlap between potential jaguar habitat models and the Central Arizona/New Mexico Recovery Area. The recovery area is $82,442 \mathrm{~km}^{2}$.

\begin{tabular}{lcr}
\hline Model & $\begin{array}{c}\text { Overlap between model extent \& Central } \\
\text { Arizona/New Mexico Recovery Area }\left(\mathrm{km}^{2}\right)(\%)\end{array}$ & $\begin{array}{c}\text { \% of area of overlap } \\
\text { considered potential habitat }\end{array}$ \\
\hline Sierra Institute (2000) & $27,256(33)$ & 79 \\
Sanderson et al. (2002b) & $5,025(6)$ & 100 \\
Menke \& Hayes (2003) & $22,834(28)$ & 99 \\
Boydston \& Lopez González (2005) & $82,422(100)$ & 69 \\
Hatten et al. (2005) & $57,537(70)$ & 82 \\
Robinson et al. (2006) & $24,885(30)$ & 100 \\
Grigione et al. (2009) & $39,289(48)$ & $51^{1}$ \\
Theobald et al. (2017) & $76,690(93)$ & $42^{2}$ \\
USFWS (2018) (model 13) & $4,942(6)$ & 55 \\
Model 14 (this study) & $82,422(100)$ & 43 \\
Model 15 (this study) & $82,422(100)$ & 68 \\
Hatten (this study) & $82,422(100)$ & 85 \\
\hline
\end{tabular}

${ }^{1}$ Another $15,258 \mathrm{~km}^{2}$ (20\% of the recovery area) was designated for further study.

${ }^{2}$ Only habitat values $>870$ in arbitrary habitat index numbers, reflecting 50\% habitat suitability (Theobald et al., 2017).

TABLE 3 Estimated potential carrying capacities (number) for adult jaguars in the USA.

\begin{tabular}{lccr}
\hline Geographical unit & Model 13 (USFWS, 2018) & Model 14 (this study) & Model 15 (this study) \\
\hline Borderlands Secondary Area-U.S. portion & 6 & 6 & 6 \\
Arizona Secondary Area & 1 & 6 & 7 \\
Central Arizona/New Mexico Recovery Area & $<1$ & 69 & 106 \\
Elsewhere in Arizona \& New Mexico & 1 & 9 & 32 \\
Total potential carrying capacity in the USA & 9 & 90 & 151 \\
\hline
\end{tabular}

We summarized potential habitat scores (i.e. habitat suitability values $>0$ ) for each of the models and calculated the area of overlap between the models and the Central Arizona/New Mexico Recovery Area boundary in Table 2. All models found some habitat in this recovery area within their study extents, varying between 42 and $100 \%$ depending on model method and extent. The five models that covered $>90 \%$ of this area (Hatten, this study; Boydston \& Lopez González, 2005; Theobald et al., 2017; models 14 and 15, this study) suggested there is $35,700-80,665 \mathrm{~km}^{2}$ of potential jaguar habitat in this region, though of variable quality. Applying the jaguar density estimation methodology used in the jaguar recovery plan, we estimated the carrying capacity for adult jaguars to be 69-100 in the Central Arizona/ New Mexico Recovery Area, and 90-151 adults in Arizona and New Mexico combined (Table 3).

\section{Discussion}

This systematic review finds that scientific models and assessments of potential habitat for the jaguar in Arizona and New Mexico indicate suitable areas north of Interstate-10 (Fig. 1). Our review of the 12 models/assessments previously conducted or reviewed here support existence of potential jaguar habitat in a region we have designated the Central Arizona/New Mexico Recovery Area (Table 2, Figs 2 \& 3). No models contradicted this finding. Even the two studies that did not explicitly consider this region (Sanderson et al., 2002b; USFWS, 2018; Fig. 2b,i, respectively) support the notion of habitat on the margins of their focal areas, which abut the Central Arizona/New Mexico Recovery Area. For those exceptions, there are corrections in later work. Grigione et al. (2009), using methods largely similar to Sanderson et al. (2002b), described a jaguar conservation unit on the Mogollon Rim (Fig. 2g). Extending the USFWS (2018) and Hatten et al. (2005) models north, as we have done here, also suggests the potential for additional habitat in central Arizona and New Mexico (Fig. 2j,k,l).

Initial estimates of carrying capacity for models 14 and 15, using essentially the same model as the approved recovery plan (i.e. model 13), push the potential of a population in the USA from six animals in Arizona and New Mexico, which the USFWS considered non-viable, to 90-151 (Table 3), which may be viable. Other well-protected, relatively isolated jaguar populations have persisted for decades with comparable population sizes, such as in Corcovado, Costa Rica with 98 jaguars; Iguazú, Argentina with 99 jaguars; and, Serra da Capivara, Brazil with 132 jaguars (see review by Zanin et al., 2015). An assessment using population viability analysis, employing the USFWS (2018) methods, is currently underway. 
This difference in potential carrying capacity, from six to 90-151 animals, is critical information about the potential for jaguar conservation in the USA. If the jaguars observed south of Interstate-10 are only occasional, dispersing males, inhabiting marginal habitat (Rabinowitz, 1999), then jaguar conservation in the USA should focus on Mexican populations and maintaining connectivity, as the USFWS (2018) recovery plan suggests. If, however, there is sufficient potential habitat north of the Northwestern Jaguar Recovery Unit, then comprehensive conservation efforts should also consider the recovery of a self-sustaining population within the USA, beginning with the recovery area identified here. The recovery plan foresees the necessity to revise the boundaries of the recovery unit in the future, noting: 'While recent survey and monitoring efforts in south-central and southeastern Arizona and extreme south-western New Mexico have provided important data, as more information is gathered on the distribution and status of jaguars within the NRU [Northwestern Jaguar Recovery Unit] and adjacent areas, the boundaries of the NRU may need to be expanded or reconfigured' (USFWS, 2018). Here we provide this information.

Novel approaches to jaguar conservation are needed because of the politics of the international border. New physical barriers and increased anti-immigration activity along this boundary (per U.S. Executive Order No. 13767, 2017) may further constrain natural dispersal to and from Mexico, isolating any potential jaguar population in the USA (Peters et al., 2018). In such a circumstance, species recovery would require establishment of a large population in the USA to ensure genetic viability and demographic sustainability. Conversely, if movements across the international boundary can be enhanced (Stoner et al., 2015), an American population might be part of a regional metapopulation structure, contributing to long-term viability. In either case bi-national collaboration will be essential (USFWS, 2018).

This systematic review highlights some important gaps in scientific knowledge about the jaguar in North America. The historical limits to the jaguar's natural range in the Americas are poorly understood, both on the contemporary northern and southern edges (e.g. Cuyckens et al., 2017). In what is now the USA, a number of intriguing, but difficult to interpret, historical observations exist from areas far beyond Arizona and New Mexico, including California, Texas, Louisiana, and other parts of the country (Sanderson \& Fisher, 2011). Relatedly, we also do not understand how climate change will affect jaguar distributions in the future (Povilitis, 2015). Culver \& Hein (2016) speculated on the basis of mitochondrial DNA differences that perhaps northern jaguars are better adapted to hot, dry conditions. Since such conditions are expected to prevail in coming decades in the south-western USA (Garfin et al., 2013), future investigations of climate effects on jaguar distributions and carrying capacity may benefit conservation efforts. At present, only one of the habitat models reviewed (Boydston \& Lopez González, 2005) included climatic variables.

The existing models are generally weak on prey availability, perhaps the most important determinant of jaguar habitat (although see Menke \& Hayes, 2003). Along the international border, jaguars prey primarily on white-tailed deer Odocoileus virginianus, javelinas Tayassu tajacu and coati Nasua narica. Farther north, cervids may be more important to jaguar diets, including white-tailed deer, mule deer Odocoileus hemionus and perhaps elk Cervus elaphus. How prey influence distribution and carrying capacity in this area needs investigation.

Populations on the periphery of a species' range may be critical to the long-term conservation of species (Lesica \& Allendorf, 1995), especially in a time of climate change (Gibson et al., 2009; Povilitis, 2015). Such populations tend to be smaller, more isolated, and more genetically and ecologically divergent than central ones, which confers on them novel evolutionary potential and local ecological significance (Leppig \& White, 2006). The recognition of additional potential habitat in the USA will, we hope, inform range-wide, as well as national, proposals for jaguar recovery (Jaguar 2030 High-Level Forum, 2018; USFWS, 2018).

The USFWS (2018) recovery plan adopted a conservative view with respect to the former distribution of jaguar habitat in the USA, despite more than 120 years of jaguar observations and nearly 2 decades of habitat models and assessments indicating the plausibility of a wider geographical distribution. This systematic review of these studies indicates that expanding consideration to areas north of the Interstate-10 highway suggests not only a stronghold of potential habitat in Arizona and New Mexico, but a new opportunity to restore the great cat of the Americas.

Acknowledgements We acknowledge support for this study from the Volgenau Foundation, Carroll Petrie Foundation, and institutional support from Defenders of Wildlife and the Wildlife Conservation Society. We thank two anonymous reviewers and the U.S. Geological Survey for helpful suggestions. Any use of trade, firm or product names is for descriptive purposes only and does not imply endorsement by the U.S. Government.

Author contributions Study design: BB, JPB, JRBM, CMB, RP, EWS; data contributions: CMB, JCB, KF, MMG, JRH, CALG, KM, PSM, MJR, RET, EWS; data analysis: KF, JRH, EWS; writing: all authors.

\section{Conflicts of interest None.}

Ethical standards This article abided by the Oryx guidelines on ethical standards.

\section{References}

Archuleta, C.A.M., Constance, E.W., Arundel, S.T., Lowe, A.J. Mantey, K.S. \& Phillips, L.A. (2017) The National Map seamless digital elevation model specifications. U.S. Geological Survey Techniques and Methods. U.S. Geological Survey, Reston, USA. 
Arizona Department of Game and Fish (2019) Arizona Game \& Fish. azgfd.com [accessed 31 March 2019].

Associated Press (1988) Two Guilty of Selling Hides. New York Times, 27 November 1988. timesmachine.nytimes.com/ timesmachine/1998/11/27/045144.html?pageNumber $=39$ [accessed 7 April 2020].

BIES, L. (2020) Court rejects jaguar critical habitat designation. The Wildlife Society, Bethesda, USA. wildlife.org/court-rejects-jaguarcritical-habitat-designation [accessed 10 November 2020].

Boydston, E.E. \& Lopez GonzÁlez, C.A. (2005) Sexual differentiation in the distribution potential of northern jaguars (Panthera onca). In USDA Forest Service Proceedings RMRS-P-36, pp. 51-56. Rocky Mountain Research Station, Fort Collins, USA.

Bravo, J.C. \& Davis, K. (2017) Four Species on the Brink and the Wall that Will Push them toward Extinction. Wildlands Network, Seattle, USA.

Brown, D.E. (1994) Biotic Communities: Southwestern United States and Northwestern Mexico. University of Utah Press, Salt Lake City, USA.

Brown, D.E. \& Lopez GonzÁlez, C.A. (2001) Borderland Jaguars: Tigres de la Frontera. University of Utah Press, Salt Lake City, USA.

Childs, J.L. (1998) Tracking the Felids of the Borderlands. Printing Corner Press, El Paso, USA.

Culver, M. \& Hein, A.O. (2016) Jaguar Taxonomy and Genetic Diversity for Southern Arizona, United States, and Sonora, Mexico. Open-File Report 2016-1109, U.S. Geological Survey, Reston, USA.

Cuyckens, G.A.E., Perovic, P.G. \& Herrán, M. (2017) Living on the edge: regional distribution and retracting range of the jaguar (Panthera onca). Animal Biodiversity and Conservation, 40, 71-86.

D Avis, T. (2013) '63 jaguar killing echoes today in habitat debate. Arizona Daily Star, 13 January 2013. tucson.com/news/science/ environment/jaguar-killing-echoes-today-in-habitat-debate/ article_9048bb7d-0729-51f9-b544-653ac5b82450.html [accessed 30 March 2020].

Garfin, G., Jardine, A., Merideth, R., Black, M. \& Leroy, S. (eds) (2013) Assessment of Climate Change in the Southwest United States: A Report Prepared for the National Climate Assessment. Island Press, Washington, DC, USA.

Gibson, S.Y., Marel, R.C.V.D. \& Starzomski, B.M. (2009) Climate change and conservation of leading-edge peripheral populations. Conservation Biology, 23, 1369-1373.

Glenn, W. (1996) Eyes of Fire: Encounter with a Borderlands Jaguar. Printing Corner Press, El Paso, USA.

Google SCHOlar (2019) scholar.google.com [accessed 3 July 2019].

Griffith, G.E., Omernik, J.M., Johnson, C.B. \& Turner, D.S. (2014) Ecoregions of Arizona. Open-File Report 2014-1141, U.S. Geological Survey, Washington, DC, USA.

Grigione, M.M., Menke, K., López-González, C., List, R., Banda, A., Carrera, J. et al. (2009) Identifying potential conservation areas for felids in the USA and Mexico: integrating reliable knowledge across an international border. Oryx, 43, 78-86.

Hatten, J.R., Averill-Murray, A. \& van Pelt, W.E. (2002) Characterizing and Mapping Potential Jaguar Habitat in Arizona. Arizona Game and Fish Department, Phoenix, USA.

Hatten, J.R., Averill-Murray, A. \& van Pelt, W.E. (2005) A spatial model of potential jaguar habitat in Arizona. Journal of Wildife Management, 69, 1024-1033.

Homer, C., Dewitz, J., YAng, L., Jin, S., Danielson, P., Coulston, J. et al. (2015) Completion of the 2011 National Land Cover Database for the conterminous United States-representing a decade of land cover change information. Photogrammetric Engineering and Remote Sensing, 81, 345-354.

Jaguar 2030 High-Level Forum (2018) Jaguar 2030 New York Statement. United Nations Development Program, New York, USA.
Leppig, G. \& White, J.W. (2006) Conservation of peripheral plant populations in California. Madroño, 53, 264-274.

LesicA, P. \& AllendorF, F.W. (1995) When are peripheral populations valuable for conservation? Conservation Biology, 9, 753-760.

McCAin, E.B. \& Childs, J.L. (2008) Evidence of resident jaguars (Panthera onca) in the southwestern United States and the implications for conservation. Journal of Mammalogy, 89, 1-10.

McKay, L., Bondelid, T., Dewald, T., Johnston, J., Moore, R. \& REA, A. (2012) NHDPlus Version 2: User Guide. U.S. Environmental Protection Agency, Washington, DC, USA.

MenKe, K.A. \& Hayes, C.L. (2003) Evaluation of the Relative Suitability of Potential Jaguar Habitat in New Mexico. New Mexico Department Game and Fish, Santa Fe, USA.

New Mexico Department of Game and Fish (2019) Conserving New Mexico's Wildlife for Future Generations. wildlife.state.nm.us [accessed 31 March 2019].

O’Leary, B.C., Kvist, K., Bayliss, H.R., Derroire, G., Healey, J.R., Hughes, K. et al. (2016) The reliability of evidence review methodology in environmental science and conservation. Environmental Science \& Policy, 64, 75-82.

Olson, D.M., Dinerstein, E., Wikramanayake, E.D., Burgess, N.D., Powell, G.V.N., Underwood, E.C. et al. (2001) Terrestrial ecoregions of the world: a new map of life on earth. BioScience, 51, 933-938.

OMERnik, J.M. \& Griffith, G.E. (2014) Ecoregions of the conterminous United States: evolution of a hierarchical spatial framework. Environmental Management, 54, 1249-1266.

Patton, D.R., Hofstetter, R.W., Bailey, J.D. \& Benoit, M.A. (2014) Species Richness and Variety of Life in Arizona's Ponderosa Pine Forest Type. RMRS-GTR-332. U.S. Forest Service, Rocky Mountain Research Station, Fort Collins, USA.

Peters, R. (2017) Bringing El Tigre Home. Defenders of Wildlife, Washington, DC, USA.

Peters, R., Ripple, W.J., Wolf, C., Moskwik, M., CarreónArroyo, G., Ceballos, G. et al. (2018) Nature divided, scientists united: US-Mexico border wall threatens biodiversity and binational conservation. BioScience, 68, 740-743.

Povilitis, T. (2002) The jaguar in the Southwest: borderland or borderline conservation? Endangered Species Update, 19, 207-213.

Povilitis, T. (2015) Recovering the jaguar Panthera onca in peripheral range: a challenge to conservation policy. Oryx, 49, 626-631.

Pullin, A.S. \& STEWART, G.B. (2006) Guidelines for systematic review in conservation and environmental management. Conservation Biology, 20, 1647-1656.

Rabinowitz, A.R. (1999) The present status of jaguars (Panthera onca) in the southwestern United States. The Southwestern Naturalist, 44, 96-100.

Riley, S.J., DeGloria, S.D. \& Elliot, R. (1999) A terrain ruggedness index that quantifies topographic heterogeneity. Intermountain Journal of Science, 5, 23-27.

Robinson, M.J., Bradley, C. \& Boyd, J. (2006) Suitable Habitat for Jaguars in New Mexico. Center for Biological Diversity, Tucson, USA.

Quigley, H., Foster, R., Petracca, L., Payan, E., Salom, R. \& Harmsen, B. (2017) Panthera onca (errata version published in 2018). In The IUCN Red List of Threatened Species 2017: e.T15953A123791436. dx.doi.org/10.2305/IUCN.UK.2017-3.RLTS. T15953A50658693.en [accessed 12 October 2020].

Sachetti-Pereira, R. (2002) Desktop GARP. University of Kansas Natural History Museum, Lawrence, USA.

Sanderson, E.W. \& Fisher, K. (2011) Digital Mapping in Support of Recovery Planning for the Northern Jaguar. Wildlife Conservation Society, New York, USA. jaguardata.info [accessed 7 April 2020].

SAnderson, E.W. \& Fisher, K. (2013) Jaguar Habitat Modeling and Database Update. Wildlife Conservation Society, New York, USA. 
Sanderson, E.W., Jaiteh, M., Levy, M.A., Redford, K.H., Wannebo, A.V. \& Woolmer, G. (2002a) The human footprint and the last of the wild. Bioscience, 52, 891-904.

Sanderson, E.W., Redford, K.H., Chetkiewicz, C.-L.B., Medellin, R.A., Rabinowitz, A.R. et al. (2002b) Planning to save a species: the jaguar as a model. Conservation Biology, 16, 58-72.

Seymour, K.L. (1989) Panthera onca. Mammalian Species, 340, 1-9.

Sierra Institute (Sierra Institute Field Studies Program in Arizona) (200o) Jaguar Habitat in Southern Arizona and New Mexico. University of California Extension, Santa Cruz, USA.

Stoner, K.J., Hardy, A.R., Fisher, K. \& Sanderson, E.W. (2015) Jaguar Habitat Connectivity and Identification of Potential Road Mitigation Locations in the Northwestern Recovery Unit for the Jaguar. Wildlife Conservation Society, New York, USA.

Theobald, D., Landau, V., McClure, M. \& Dickson, B. (2017) Potential Jaguar Habitat and Structural Connectivity in and Surrounding the Northwestern Recovery Unit: Report to Wilburforce Foundation. Conservation Science Partners, Fort Collins, USA.

U.S. EXECUTIVE ORDER 13767 (2017) Border Security and Immigration Enforcement Improvements. Federal Register, 82, 8793-8797.

U.S. Department of the Interior Office of Inspector General (2010) Macho B. Investigative Report, Washington, DC, USA.

USFWS (U.S. Fish And Wildlife Service) (1972) Conservation of endangered species and other fish or wildlife. List of endangered foreign fish and wildlife. Federal Register, 37, 6476.

USFWS (U.S. Fish and Wildlife Service) (1975) Endangered and threatened wildlife and plants: reclassification of American alligator and other amendments. Federal Register, 40, 444111-444429.

USFWS (U.S. Fish and Wildifie Service) (1979) Endangered and threatened wildlife and plants; U.S. populations of seven endangered species. Federal Register, 44, 43705.

USFWS (U.S. Fish and Wildlife Service) (1980) Endangered and threatened wildlife and plants, proposed endangered status for U.S. populations of five species. Federal Register, 45, 49844-49487.
USFWS (U.S. Fish AND Wildlife Service) (1982) Endangered and threatened wildlife and plants; notice of withdrawal of expired proposal for listing of U.S. Populations of thick-billed parrot, short-tailed albatross, Margay cat, \& jaguar. Federal Register, $47,41145$.

USFWS (U.S. Fish And Wildlife Service) (1990) Listed Cats of Texas and Arizona Recovery Plan (with Emphasis on the Ocelot). USFWS, Albuquerque, USA.

USFWS (U.S. Fish and Wildlife Service) (1994) Endangered and threatened wildlife and plants; proposed endangered status for the jaguar in the United States. Federal Register, 59, 35674-35679.

USFWS (U.S. Fish and Wildlife Service) (1997) Endangered and threatened wildlife and plants; final rule to extend endangered status for the jaguar in the United States. Federal Register, 62, 38147-39157.

USFWS (U.S. Fish and Wildlife Service) (2006) Endangered and threatened wildlife and plants; determination that designation of critical habitat is not prudent for the jaguar. Federal Register, 71, 39335-39337.

USFWS (U.S. Fish and Wildlife Service) (2010) Endangered and threatened wildlife and plants; determination that designation of critical habitat is prudent for the jaguar. Federal Register,

75, 1741-1744.

USFWS (U.S. Fish and Wildlife Service) (2014) Endangered and threatened wildlife and plants; designation of critical habitat for jaguar: final rule. Federal Register, 79, 12572-12654.

USFWS (U.S. Fish and Wildlife Service) (2016) Jaguar Draft Recovery Plan (Panthera onca). USFWS, Albuquerque, USA.

USFWS (U.S. Fish AND Wildlife SeRvice) (2018) Jaguar Recovery Plan (Panthera onca). USFWS, Albuquerque, USA.

USFWS Arizona Ecological Services (2019) Panthera onca. fws.gov/southwest/es/arizona/Jaguar.htm [accessed 31 March 2019]. USFWS \& Wildlife Conservation Society (2020) Jaguar Observations Database. jaguardata.info [accessed 7 April 2020].

Zanin, M., Palomares, F. \& Brito, D. (2015) The jaguar's patches: viability of jaguar populations in fragmented landscapes. Journal for Nature Conservation, 23, 90-97. 